\section{B A Institute of \\ YK Business Administration \\ 六下 \\ Karachi \\ Leadership and Ideas for Tomorrow}

Business Review

Volume 4 Issue 1 January-June 2009

$1-1-2009$

\title{
Asian financial crisis 1997: An empirical investigation
}

Khurshid M. Kiani

Bang College of Business, Republic of Kazakhstan

Follow this and additional works at: https://ir.iba.edu.pk/businessreview

Part of the Finance and Financial Management Commons

(c) (7)

This work is licensed under a Creative Commons Attribution 4.0 International License.

\section{Recommended Citation}

Kiani, K. M. (2009). Asian financial crisis 1997: An empirical investigation. Business Review, 4(1), 133-142. Retrieved from https://doi.org/10.54784/1990-6587.1169 


\title{
ARTICLE
}

\section{Asian Financial Crisis 1997: An Empirical Investigation}

\author{
Khurshid M. Kiani \\ Bang College of Business, Republic of Kazakhstan
}

\begin{abstract}
Multinomial Asian Financial Crises are said to happen because of financial mismanagement due to post Bretton Woods era financial liberalization, enhancement in private sector debt, currency crises, investor panic as well as inept attitude of the governments in these countries after start of the crises. Since Taiwan is the only country that was not hit as hard as the other countries in the region due to the brunt of these crises we decided to analyze its firm structure to unfold the causes of its survival.
\end{abstract}

Our analysis reveal evidence that manager operated firms finances their growth through external finance without taking into account the profitability of the firm. Contrary to this, the owner operated firms finance their growth from earned profits. This is a possible explanation of why Taiwan was not affected seriously due to 1997 Asian financial crisis because most Taiwanese firms are operated by owners or managers who are loyal to the business of the family.

Keywords: owner-controlled firms; management-controlled firms; control type; financial crisis

JEL Codes: C31, C40, D92;

Word Count- Main Text: 2901

\section{INTRODUCTION}

East and South East Asian countries i.e. Indonesia, Republic of Korea, Malaysia, Philippines, Singapore, and Thailand encountered financial crises from July 1997 to February 1998. The worst hit among them was Indonesia whose stock market declined to about more than 80 percent and exchange rate vis-à-vis US dollar fell by almost 75 percent (Singh 1998). Although the currency crises and stock market decline was one aspect of the financial crises in these countries, the other aspects that include macroeconomic imbalances, decline in export growth, decline in property prices, as well contagion effect and state controlled financial system in these countries all are reported to be causes of the Asian financial crises. 
Although there are a number of hypotheses that include capital supply shock, financial liberalization and so forth, there appeared no advance warning of such crises as international financial institution like World Bank and IMF strongly commended growth and economic development in these countries. For example, the World Bank Economist in their research in 1991 entitled "World Development Report: The Challenge of Development" claimed that East Asian countries were successful because they followed a market-friendly strategy of development and integrated their economies closely with that of the world economy assuming that governments of these countries intervene reluctantly, and if it becomes necessary, it should be transparent and should be subject to check and balances. However, later they figured it out that the governments in these countries pursue only export oriented policies and therefore, in another publication in 1993 entitled "The East Asian Miracle: Economic Growth and Public Policy” the World Bank economists significantly changed their characterization of the East Asian model because of fully acknowledged enormous government interventions in these economies.

Yilmaz Akyüz (2000) concluded that the 1997 Asian financial crises emerged due to systemic global financial instability that appeared after the collapse of the Bretton Woods systems that enhanced liberalization and mobility of international capital flows. However, some kind of financial mismanagement appeared to be common among all the East and Southeastern Asian countries that were followed by the inept attitude of the governments in these countries in implementing timely policy actions. For example, Thailand, political disarray at various times during 1996-97, including in the wake of the November 1996 general election, delayed the implementation of necessary policy measures to avert financial crises in the economy.

There are a number of arguments why 1997 Asian Financial Crises were so different and unpredictable when compared to financial turmoil experienced in other parts of the world. Most financial crises in the post-Bretton Woods era are said to happen because of a combination of currency instability with banking crises, which has historically been preceded particularly by financial liberalization of the economy. That is the reason why all episodes of financial crises started by sharp increase in capital inflows followed by a similar turnaround which caused the world economy to witness consecutive repeated bouts of financial instability in early 90s i.e. a debt deflation in the United States and thereafter the crisis in Europe in 1992-1993 which was followed by the Mexican crisis of 1994-1995 and by the East Asian crisis beginning in 1997, and thereafter crises in Brazil and in the Russian Federation. Needless to say that world economy also witnessed repeated bouts of financial crises in transition economies particularly in Finland because of liberalization of the financial sector in the economy.

Another argument why financial crises in emerging markets occurred under varying macroeconomic conditions e.g. current-account deficits, budget deficits and external 
debts. For example crises in Mexico and Thailand occurred when these countries had large and unsustainable current-account deficits, although in Indonesia and the Russian Federation such deficits where very small. However, financial crises in Brazil and the Russian Federation were coupled with large budget deficits and the debts were owed primarily by the public sector whereas both Mexico and East Asia had either balanced or surplus budgets and debts were owed primarily by the private sector. Finally, Brazil, Mexico and the Russian Federation all experienced financial crises due to currency turmoil that happened in bringing down the inflation but in most these East Asian countries the appreciation of the currency was moderate or negligible.

Out of all these episodes of financial crises, the Asian crisis was generally more difficult to predict than the Mexican, Russian or Brazilian crises. This is important because these economies had been examples of prudent and sustainable economic policies. The crisis in East Asia, like crises almost everywhere else, was preceded by a sharp increase in capital flows to the region. Starting in the early 1990s, there was a rapid increase in short-term lending by commercial banks to both banks and firms in the region. Most bank lending was non-syndicated that was directed to non-financial private firms. Such transactions must have been perceived to be profitable by both international lenders and the Asian borrowers. However, it turned out that more capital flowed into these economies than could have been profitably used at modest risk; i.e. there was a misjudgment of return and risks by both lenders and borrowers. Pomerleano (1998) noted that there was an excessive investment in these countries without taking into account poor returns on these investments.

A number of researchers that include Radelet and Sachs (1998), Marshall (1998), and Chang and Velasco (1999) demonstrate that the Asian crises in 1997 propagated over time mainly because of sudden shifts in market expectations and confidence followed by regional contagion. While admitting the worsening of the macroeconomic performance of some affected countries in the mid-1990s, this view suggests that the extent and depth of the crisis should not be attributed to deterioration in fundamentals, but rather to panic on the part of domestic and international investors. According to this view, fundamental imbalances triggered the currency and financial crisis in 1997 even after the crisis started; market overreaction caused the plunge in exchange rates, assets prices, and economic activity more severe than what one would have expected because of initial weak economic conditions in these countries.

In the present research, however, we argue that Asian crises and any other crises can be averted with macroeconomic policy that has microeconomic foundations. As mentioned in the previous paragraphs, most debts were owed by private sectors and government policies of intervention were not followed and as such the policy actions were inept at the start of the crises. We do not argue for financial liberalization nor 
we have a counter proposal on it but we think that there should be some kind of financial discipline at firm level that should be related to a typical external financing that might help a situation where excessive financial mobility would be minimized to support the related macroeconomic policy that could avert a future financial crises like 1997 Asian Financial Crises. For the same reason, we study conservative financial firm structure of Taiwanese firms if that was the reason why Taiwan was not much affected by the 1997 Asian Financial Crises as hard as other countries in the region did.

\section{RELATED LITERATURE}

Despite substantial growth in corporate culture in developed countries especially in North America, the question whether ownership should be separated from control is still un-answered although researchers since Berle and Means (1932) have been trying to explore whether firm ownership should be separated from control because mangers tend to obviate from profit or present-value maximization of the firms (Lee 1990) and set other goals such as lifetime income (Mosen and Downs 1965), sales volume (Baumol 1959), growth rate (Marris 1964), or staff expenditure (Williamson 1964). Indeed, managers' profit-satisficing behavior might be acceptable to some owners (Colli 2003) who operate family-run and closely-held firms because they might have additional goals distinct from pure profit-maximization. That is why Penrose (1995) characterizes firm owners in two categories, which are productminded entrepreneurs and empire builders.

Although this is the main principle in the context of agency theory, its innovation is the result of a misaligning of interests between Berle and Means, as Berle saw a project with a new conception of property, contrary to Means who recommend separation of management from control (Nodoushani and Nodoushani 1999). Because of asymmetric information due to separation of ownership from control, highly dispersed stockholders will not be able to evaluate managers' performance (Jensen and Meckling 1976). Moreover, separation of ownership from control is the cause of asymmetric information in corporate relationships, which could lead to different business behaviors. To solve this problem, Leibenstein (1966) suggests tying managers' compensation with their performance. However, managerial performance is more likely to become unsatisfactory when a corporation attains significant market power (Williamson 1964), or capital market imperfections develop (Smiley 1976), or managers do not receive ample incentives in their contracts (Williamson 1985), or when it is difficult to replace managers (Fama 1980).

Compared to the United States of America, Taiwan has family-owned or controlled corporate enterprises that tend to have a large degree of separation of ownership from control in the Asian region (Claessens, Djankov, and Lang (2002). Separation 
of ownership from control in large firms in Taiwan is evident but is often illusionary because managers may be picked on the basis of loyalty to the family than competence. In addition, corporate governance structures in Asia are not very well organized and there is a great risk of minority shareholder rights expropriation (Claessens and Fan, 2002; Johnson et al. 2000). This can lead to higher profitability but reduces accountability, which can be attributed to be one of the factor that caused late 1990s Asian financial crises (Iu and Batten, 2001).

Indeed, separation of ownership and control can lead to an inability to monitor managerial performance in the context of highly dispersed stockholders (Jensen and Meckling 1976). Thus, a firm can be thought of as a nexus of contracts and the growth of the corporation could be attained through reduction of transaction costs (Coase 1937). However, the complexity of corporate relationships leads to asymmetric information that is why New Institutional Economics argues that the separation of ownership from control may lead to different business behaviors.

In the present research, we focus on the possibility of growth maximization of the firm as well as investigate if the interests of managers and owners are misaligned. Therefore, in the analysis, a managerial growth constraint is incorporated to anticipate the possible impact of control type on financial crises. Moreover, we investigate how Taiwan was able to weather the storm of the Asian financial crises in 1997, a problem that others including Wang (2000) have investigated at more macroeconomic rather than firm level. The remaining paper is organized as follows. Section 2 incorporates related literature, and in section 3 we present an overview of corporate governance in Taiwan. Section 4 presents our empirical approach and discussions. Finally section 5 incorporates conclusion that can be drawn from the paper.

\section{CORPORATE GOVERNANCE IN TAIWAN}

Compared to the U.S.A., Taiwan has a higher degree of family-owned or controlled large corporate enterprises. Claessens, Djankov, and Lang (2002) noted that there tends to be a large degree of separation of management from control within family firms in the Asian region, especially in Taiwan. This separation of management from control is evident within the larger firms in Taiwan, exhibiting a similar pattern to that of the United States, but this separation is often illusionary because managers may be picked more on the basis of loyalty to the family than due to managerial competence. Thus, while in the United States, managers may rise due to managerial competence but have little loyalty to the interests of the corporation, Taiwanese managers may be more loyal but less managerially competent. In addition, corporate governance structures in Asia are not very well organized and there is a great risk of minority shareholder rights expropriation (Claessens and Fan 2002; Johnson et al 2000). This can lead to greater profitability in some respects but it reduces 
accountability, which has been noted as one factor causing the East Asian economic crisis of the late 1990s (Iu and Batten 2001).

We would expect that there will be differences between management-controlled firms and owner-controlled firms. Given that members of families tend to exhibit similar preferences on risk and that family owned businesses may be seen as having an importance to the family that goes beyond profit considerations, we would expect that family controlled businesses would engage in practices that would be more risk averse and thus would lead to reduced profitability in the short run, but greater likelihood of survival. We do not directly test the profitability question in this paper but if firms undertake a conservative approach to financing growth this would be consistent with our hypothesis that owner controlled firms will finance growth out of profits while manager controlled will use equity and leveraging strategies for firm growth.

\section{EMPIRICAL APPROACH}

Our analysis draws heavily from the results contained in Chen, Kiani, and MadjidSadjadi (2007) wherein they employed data from 300 Taiwanese corporations which were they obtained from the publications of the Taiwanese Management Securities Commission volume 20, No.1 2002, and the Review of the Investment Information No. 12, 2000. In their analysis, Kiani and Madjid-Sadjadi (2007) segregated the selected Taiwanese firms in various groups using discriminant analysis, and incorporated managerial resource constraint in the analysis due to Penrose (1995) to discipline managers. Further, they concluded that control type had significant effect on the firm growth in Taiwan.

Taiwanese firms are controlled by family relationship. In this context Godajlovic and Shapiro (2005) maintained that Taiwanese firms are controlled more by family relationships than would be obvious by merely looking at the extent of holdings by these individuals. Thus, the control of Taiwanese firms is maintained through cultural norms and placement in management from the members of the family or those who are loyal to the family.

The chief hypothesis of interest of this research is whether control type has an impact (if any) on the growth of the firms as well as if the firm data would be advantageous to explain the reasons how Taiwan escaped from the 1997 Asian financial crises whereas other did not. Our results that are based on the results drawn from in Chen, Kiani and Madjid-Sadjadi (2007) show that because of conservative corporate structure most Taiwanese corporations are controlled by the owners or the manager loyal to the family. These firms finance their growth from earned profits rather than borrowed funds. This is crucial in understanding why Taiwan suffered for less in the 1997 Asian Financial crises that did other economies in the region. 


\section{DISCUSSIONS}

Glancey (1998) notes that among entrepreneurs who have not ceded control, larger firms grow faster than smaller firms and younger firms grow faster than the wellestablished firms. James (1999) suggested that family firms where management and control are interwoven allow them to have longer time horizons than firms where management-control is present. In addition, agency costs are reduced, enabling greater profitability.

Managerial-controlled firms are more likely to exhibit a tendency towards a shorter time horizon associated with a need to address maximization of the present-value of the firm via stock price changes (the traditional mechanism for determining profit maximization of corporations within the neoclassical framework), while family firms may be more concerned with riskier long-term goals (Harris, Martinez and Ward 1994). At the same time, arguments between family owners may provide a greater degree of managerial autonomy even with close corporate supervision as managers align themselves with one faction or another (Davis and Harveston 2001). Alternatively, when managers see themselves serving the interests of the family, or when they come from the family itself, this can lead to greater strategy cohesion compared to non-family firms (Ensley and Pearson 2005).

Most Asian countries that faced the 1997 financial crisis borrowed heavily for financing their growth because a common reason for sustainability of high growth in these countries was excessive investment through debt financing without taking into account the poor returns on these investments (Pomerleano 1998). However, because of the conservative corporate structure where most firms have a strongly binding growth constraint, Taiwan was able to weather the storm better than the other East Asian countries.

\section{CONCLUSION}

This paper is an extension to Chen, Kiani and Madjid-Sadjadi (2007) wherein the empirical validity of the growth hypothesis due to Berle and Means (1935) is investigated. The analysis includes managers' resource constraint that impedes the managers' actions to deviate from shareholders goals. Therefore, the present research investigates the reasons that made Taiwan get away from the 1997 Asian financial crises.

Since most Taiwanese firms are owner controlled or controlled by the managers loyal to the family, management of these firms finance their growth from the earned profits. Interestingly, such firms willingly obviate opportunities for risky short term profits in exchange for steady long term sustainability. Based on these observations, 
we can conclude that most Taiwanese firm did not finance their growth from external borrowings; Taiwan was saved from the brunt of the 1997 Asian financial crises.

\section{REFERENCES}

Berle, A., and G. Means 1935, The Modern Corporation and private property, New York: McGraw-Hill.

Baumol, William J., 1959, Business Behavior, value and growth. New York: Macmillan.

Chang, R., and A. Velasco, 1999, Liquidity crises in emerging markets: Theory and policy. NBER Working Paper Series No. 7272, National Bureau of Economic Research, Massachusetts.

Chen, E. Kiani, K. and Madjid-Sadjadi, Z. 2007, Impact of Control Type on Firm Growth in Taiwan, International Journal of Applied Economics, 4(1), 76-84.

Claessens, Stijn, Simion Djankov, and Larry Lang, 2000, The separation of ownership and control in East Asian Corporations, Journal of Financial Economics 58: 81-112.

Claessens, Stijn, and Joseph Fan, 2002, Corporate governance in Asia: A Survey, International Review of Finance 3: 71-103.

Coase, Ronald, 1937, The nature of the firm, Economica 4: 386-405.

Colli Andrea, 2003, The history of family business, 1850-2000, Cambridge University Press: Cambridge England.

Davis, Peter S., and Paula D. Harveston, 2001, The phenomenon of substantive conflict in the family firm: A cross-generational study, Journal of Small Business Management, 39: 14-30.

Ensley, Michael D., and Allison W. Pearson, 2005, An exploratory comparison of the behavioral dynamics of top management teams in family and nonfamily new ventures: cohesion, conflict, potency, and consensus, Entrepreneurship Theory and Practice, 29: 267-284

Fama, Eugene, 1980, Agency problems and the theory of the firm, Journal of Political Economy 88: 288-307. 
Glancey, K., 1998, Determinants of Growth and Profitability in Small Entrepreneurial Firms,” International Journal of Entrepreneurial Behaviour and Research 4(1): 18-27.

Godajlovic, Eric, and Daniel M. Shapiro, 2005, Ownership structure and firm profitability in Japan, Academy of Management Journal 45: 565-575.

Harris, Dawn, Jon Martinez, and John Ward, (1994), Is Strategy Different for the Family-Owned Business, Family Business Review 7: 159-174.

Iu, Justin, and Jonathan Batten, 2001, The Implementation of OECD corporate governance principles in post-crisis Asia, Journal of Corporate Citizenship 4: 47-61.

James, Harvey, 1999, Owner as Manager, Extended Horizons and the Family Firm, International Journal of the Economics of Business, 6: 41-55.

Jensen, M., and W. Meckling, 1976, Theory of the firm: managerial behavior, agency costs and ownership structure, Journal of Financial Economics 3; 305-60.

Johnson, Simon, Peter Boone, Alasdair Breach, and Eric Friedman, 2000, Corporate Governance in the Asian Financial Crisis, Journal of Financial Economics 58: 141186.

Lee, Frederic S., 1990, The modern corporation and Gardiner Means's critique of neoclassical economics, Journal of Economic Issues, XXIV (September): 673-691.

Leibenstein, Harvey, 1966, Allocative efficiency vs. X-efficiency, American Economic Review 56:392-415.

Marshall, D., 1998, Understanding the Asian Crisis: Systemic Risk as Coordination Failure, Economic Perspective Third Quarter:13-28. Federal Reserve Bank of Chicago.

Morris, Robin, 1964, The Economic Theory of Managerial Capitalism, London: Macmillan.

Mosen Joseph, and Anthony Downs, 1965, A theory of large managerial firms, Journal of Political Economy 73: 221-236.

Nodoushani, Omid, and Patricia A. Nodoushani, 1999, The debate on corporate governance: an historical analysis of Berle and Means contributions, The Journal of Behavioral and Applied Management, 1: 55-66. 
Pomerleano, Michael, 1998, The East Asia and Corporate Finances: the Untold Micro story. Working paper, World Bank, October.

Penrose, Edith 1995, The Theory of the Growth of the Firm. New York: Oxford University Press.

Radelet, S., and J. Sachs, 1998, The Onset of the East Asian Financial Crisis. NBER Working Paper Series No. 6680, National Bureau of Economic Research, Massachusetts.

Singh, Agit, 1998, Asian Capitalism and the Financial Crisis, Center for Economic Policy Analysis (CEPA) Working Paper Series III, Working Paper No. 10, New York, NY.

Smiley, Robert H., 1976, Tender Offers, Transaction Costs and the Theory of the Firm, Review of Economics and Statistics 58: 22-32.

Radelet, S., and J. Sachs, 1998, The Onset of the East Asian Financial Crisis. NBER Working Paper Series No. 6680, National Bureau of Economic Research, Massachusetts.

Wang, Jiann-Chyuan, 2000, Taiwan and the Asian financial crises: Impact and response. In Chow, Peter, C. and Gill, Bates, (eds). Weathering the Storm: Taiwan, its Neighbors, and the Asian Financial Crises. Washington D.C.: Brookings Institute.

Williamson, Oliver E., 1964, The Economics of Discretionary Behavior: Managerial Objectives in a Theory of the Firm. Englewood Cliffs, NJ: Prentice-Hall. 1985, The Economic Institutions of Capitalism, New York: Free Press.

World Bank, 1993, The East Asian Miracle: Economic Growth and Public Policy, New York: Oxford University Press for the World Bank.

World Bank, 1991, World Development Report: The Challenge of Development, NewYork: Oxford University Press for the World Bank.

Yilmaz, Akyüz, 2000, Causes and Sources of the Asian Financial Crisis, Symposium on Economic and Financial Recovery in Asia, UNCTAD X, Bangkok, 17 February 2000. 